\title{
Declaración de Lima sobre el consumo de leche de vaca en menores de 01 año
}

\author{
Declaration of Lima on the consumption of cow's milk in children under 01 year

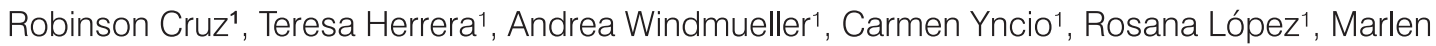

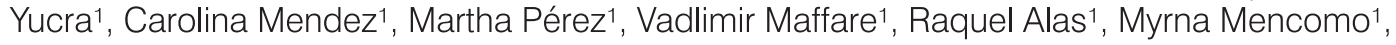 \\ Claudia Maza ${ }^{1}$, Raquel Franco ${ }^{1}$, Edna Nava ${ }^{1}$ \\ ${ }^{1}$ Coordinador País del Comité Internacional para la elaboración de consensos y estandarización \\ en nutriología (CIENUT) \\ E-mail: comiteinternacional@iidenut.org
}

Capacidades adquiridas: Al finalizar el artículo, los lectores podrán:

Describir las características bioquímicas de la leche de vaca

$>$ Describir las características de la proteína de la leche de vaca

$>$ Describir los mecanismos propuestos que asocian la leche de vaca con microsangrados

\begin{abstract}
Resumen
Los firmantes, coordinadores de los Capítulos nacionales integrantes del Comité Internacional para la Elaboración de Consensos y Estandarización en Nutriología (CIENUT), después de un proceso profundo de discusión y análisis que involucró a la totalidad de nuestros miembros, declaramos lo siguiente:
\end{abstract}

La anemia por deficiencia de hierro es un problema de Nutrición Pública que afecta en grados variables, pero significativos, a la población de todos los países latinoamericanos y presenta algunos factores que vienen contribuyendo a esta situación. La prevalencia de lactancia materna exclusiva, por ejemplo, ha caído sostenidamente en el último quinquenio; la introducción de alimentos diferentes a la leche humana se produce en promedio a partir de los 4 meses y es la leche de vaca uno de los alimentos más empleados como sustituto de la leche humana. Dada las características bioquímicomoleculares de la proteína de la leche de vaca su consumo antes del año de vida contribuye significativamente a agudizar el problema de anemia en poblaciones de riesgo.

En este contexto, hemos elaborado la Declaración de Lima sobre el consumo de leche entera de vaca en menores de un año; esta declaración busca generar conciencia entre las autoridades de salud sobre lo siguiente:

> Difundir que las características bioquímicas de la proteína de la leche entera de vaca pueden generar microsangrados a nivel intestinal cuando es administrada en niños de 0 a 1 año.

> Promover la lactancia materna exclusiva los primeros 6 meses de vida y la alimentación complementaria a partir de los 6 meses.

$>$ Promover la lactancia materna hasta los 2 años. 
Invocamos, además, a todas las instituciones que brindan atención nutricional suscriban este consenso y hagan todo lo necesario para que pueda implementarse en la forma más rápida posible.

Firmado el 14 de setiembre de 2019 en Lima, Perú.

Palabras clave: anemia ferropénica, caseina, leche de vaca, microsangrados.

\section{Summary}

The signatories, coordinators of the National Chapters of the International Committee for the Development of Consensus and Standardization in Nutritionology (CIENUT), after an in-depth discussion and analysis process that involved all of our members, declare the following:

Iron deficiency anemia is a Public Nutrition problem that affects the population of all Latin American countries in varying degrees, but it has some factors that contribute to this situation. The prevalence of exclusive breastfeeding, for example, has fallen steadily in the last five years; The introduction of foods other than human milk occurs on average after 4 months and cow's milk is one of the most commonly used foods as a substitute for human milk. Given the biochemical-molecular characteristics of cow's milk protein, its consumption before the year of life contributes significantly to the problem of anemia in risk populations.

In this context, we have prepared the Lima Declaration on the consumption of whole cow's milk in children under one year; this statement seeks to raise awareness among health authorities about the following:

> Disseminate that the biochemical characteristics of whole cow's milk protein can generate micrograins at the intestinal level when administered in children aged 0 to 1 year.

$>$ Promote exclusive breastfeeding the first 6 months of life and complementary feeding from 6 months.

$>$ Promote breastfeeding up to 2 years.

We also invoke all the institutions that provide nutritional care to subscribe to this consensus and do everything necessary so that it can be implemented as quickly as possible.

Signed on September 14, 2019 in Lima, Peru.

Key words: iron deficiency anemia, casein, cow's milk, microbleeds. 